\title{
HUBUNGAN ANTARA RASA PERCAYA DALAM HUBUNGAN ROMANTIS DAN KEKERASAN DALAM PACARAN PADA PEREMPUAN DEWASA MUDA DI JAKARTA
}

\author{
Sheila Grace ${ }^{1}$, Pradipta Christy Pratiwi, \& Grace Indrawati \\ Fakultas Psikologi, Universitas Pelita Harapan, Jl. MH. Thamrin Boulevard, Lippo Karawaci, Jakarta 15811, \\ Indonesia
}

Korespondensi:

'e-mail: gracegrace317@gmail.com

\begin{abstract}
Conflict in close relationships are inevitable and likely to occur as a consequence of interpersonal disagreement. Conflict can be resolved if parties are open to communicate and being honest with each other. However, it is common to find individuals who employ violence as an approach to resolve relationship conflicts. Women tend to experience dating violence because they are positioned lower and perceived weaker than men. This research uses quantitative method, specifically correlational technique, to determine the relationship between the two variables. Total 165 samples of young adult women in line with the research criterias were obtained using purposive sampling. The scales used in this research are the Trust Scale and the adapted version of The Revised Conflict Tactics Scale. The result showed that there is a significant negative correlation between trust in close

relationship and dating violence among young adult women in Jakarta.
\end{abstract} Article history:

Received 4 April 2018

Received in revised form 3 May 2018

Accepted 6 June 2018

Available online 21 September 2018

Keywords:

dating relationship;

dating violence;

trust in close relationship

\begin{abstract}
Abstrak - Perbedaan pendapat dengan pasangan merupakan hal yang tidak dapat dihindari dan biasanya menjadi sebuah pemicu timbulnya konflik dalam hubungan pacaran. Konflik dalam hubungan pacaran dapat diselesaikan dengan baik apabila pasangan bersikap secara terbuka dan jujur dalam berkomunikasi. Namun, tak jarang ditemukan adanya penggunaan tindak kekerasan sebagai metode untuk menyelesaikan konflik dalam hubungan pacaran. Perempuan seringkali dijadikan korban kekerasan dalam pacaran karena dianggap lemah dan memiliki kedudukan di bawah laki-laki. Penelitian ini menggunakan metode kuantitatif dengan teknik korelasi. Sebanyak 165 sampel yang sesuai dengan karakteristik penelitian diperoleh dengan menggunakan teknik purposive sampling. Alat ukur yang digunakan dalam penelitian ini adalah Trust Scale dan adaptasi alat ukur The Revised Conflict Tactics Scale atau CTS2. Hasil dari penelitian ini menunjukkan adanya hubungan negatif yang signifikan antara rasa percaya dalam hubungan romantis dan kekerasan dalam pacaran pada perempuan dewasa muda di Jakarta.
\end{abstract}

Kata Kunci: hubungan pacaran; kekerasan dalam pacaran; rasa percaya dalam hubungan romantis 


\section{PENDAHULUAN}

Kekerasan dalam pacaran masih banyak terjadi di kalangan masyarakat luas. Komisi Nasional Perempuan (2015) mencatat adanya laporan kekerasan dalam pacaran pada tahun 2014 sebanyak 1.748 kasus. Jumlah ini meningkat pada tahun 2015 menjadi 2.734 kasus (Komisi Nasional Perempuan, 2016).

Indraswari mengungkapkan bahwa perempuan rentan terhadap kekerasan (dalam Erdianto, 2016). Hal ini diperkuat oleh lemahnya penegakan hukum untuk keadilan bagi korban kekerasan di Indonesia serta adanya ketimpangan relasi gender. Sesuai dengan gagasan Poerwandari (dalam Putri, 2012; Firestone \& Catlett, 2003), perempuan cenderung dianggap memiliki kedudukan yang lebih rendah dan merupakan makhluk yang lemah jika dibandingkan dengan laki-laki. Pandangan ini mendorong perlakuan kekerasan terhadap perempuan sebagai taktik penyelesaian konflik interpersonal yang biasa bagi masyarakat (Straus \& Scott, dalam Putri, 2012).

Kekerasan dalam pacaran dikenal sebagai perilaku agresi dan penuh kontrol terhadap pasangan. Jenis kekerasan yang dialami oleh korban dapat berupa psikologis, fisik, seksual, maupun kombinasi (National Center for Victims of Crime, 2012). Terdapat rangkaian dampak negatif bagi korban yang mengalami kekerasan dalam pacaran, baik jangka pendek maupun jangka panjang (American Psychological Association, 2002). Dampaknya dapat bervariasi, mulai dari cedera atau luka fisik (Straus, Hamby, McCoy, \& Sugarman, 1996) hingga dampak yang berpengaruh terhadap kesehatan mental, misalnya: gangguan kecemasan, rendahnya self-esteem (Kaukinen, Buchanan, \& Gover, 2015), Post-traumatic Stress Disorder (PTSD), hingga depresi (Lee, Pomeroy, \& Bohman, 2007). Menanggapi fenomena kekerasan dalam pacaran, Walker (1979) membentuk siklus kekerasan dalam hubungan romantis. Siklus tersebut mencakup tiga bagian, yaitu fase tension building (adanya konflik yang memuncak pada pasangan, sehingga menimbulkan perseteruan), fase violence (korban mengalami kekerasan dalam bentuk psikologis, fisik, hingga seksual), dan fase honeymoon (pelaku menampilkan rasa bersalah, meminta maaf pada korban, dan berjanji untuk tidak melakukannya kembali). Melalui pernyataan tersebut, dapat dikatakan bahwa kekerasan dalam pacaran seringkali digunakan sebagai metode dalam penyelesaian konflik yang tidak sehat.

\section{Kekerasan dalam Pacaran}

Straus (2004) mendefinisikan hubungan pacaran sebagai hubungan bersifat dua arah (dyadic relationship), yang disertai dengan adanya pertemuan untuk berinteraksi maupun melakukan 
aktivitas bersama. Hubungan pacaran dikenal dapat membantu kedua pihak untuk membentuk komitmen dalam hubungan romantis yang lebih mendalam, yaitu pernikahan. Meski demikian, hubungan pacaran tidak dapat lepas dari terjadinya konflik. Konflik dapat bermanfaat untuk mematangkan hubungan romantis (Howe, 2002). Selain dikenal sebagai hal yang tidak dapat dihindari pada pasangan (Brehm, Miller, Perlman, \& Campbell, dalam Ross, 2015), konflik juga seringkali muncul karena terjadinya ketengangan akibat perbedaan pendapat pada pasangan (Gottman, dalam Ross, 2015). Kunci kesuksesan dalam menyelesaikan konflik yang baik ialah dengan cara bersikap terbuka dan jujur dalam berkomunikasi, bukan dengan meluapkan emosi yang cenderung meledak-ledak (Gottman, dalam Ross, 2015). Akan tetapi, seringkali pasangan menggunakan tindak kekerasan sebagai taktik penyelesaian konflik hubungan romantis (Scott \& Straus, dalam Putri, 2012). Oleh sebab itu, individu memiliki tantangan untuk dapat menyelesaikan konflik secara sehat dengan pasangannya (Howe, 2002).

Kekerasan dalam pacaran merupakan perilaku agresi terhadap pasangan dalam bentuk kekerasan psikologis, fisik hingga seksual (Joly \& Connolly, 2016). Menurut Straus dkk., (dalam Putri, 2012), terdapat empat dimensi dalam kekerasan dalam pacaran, di antaranya negosiasi (negotiation), agresi psikologis (psychological aggression), kekerasan fisik (physical assault), dan kekerasan seksual (sexual coercion). Negosiasi merupakan langkah pasangan dalam menyelesaikan konflik dengan melakukan diskusi dan menyampaikan perasaan pada pasangan (Straus dkk., 1996). Agresi psikologis merupakan jenis kekerasan yang disertai adanya perilaku yang merendahkan, membatasi, menyinggung, hingga mengancam pasangan (O’Leary \& Maiuro, dalam Capaldi, Knoble, Shortt, \& Kim, 2012). Kekerasan fisik merupakan kekerasan yang didasari oleh intensi untuk menyakiti fisik pasangan secara intens (Capaldi dkk., 2012), mulai dari menampar hingga mencekik (Straus, 2004). Kekerasan seksual merupakan perilaku yang memaksakan kehendak pasangan untuk melakukan aktivitas seksual (Straus dkk., 1996).

Terdapat beberapa faktor yang berpotensi memengaruhi kekerasan dalam pacaran, di antaranya usia individu (Johnson, Giordano, Manning, \& Longmore, 2015), ketidaksetaraan gender (Llyod, dalam Few \& Rosen, 2005; Scott \& Straus, dalam Putri, 2012), suku dan budaya (Capaldi dkk., 2012; Archer, dalam Chan, Straus, Brownridge, Tiwari, \& Leung, 2008), rasa cemburu (Himawan, 2017), pengaruh dari teman individu (Jolly \& Connolly, 2016), pengalaman mengalami kekerasan saat masa kecil (Kaukinen, Buchanan, \& Gover, 2015), serta toleransi individu terhadap kekerasan (Deal \& Wampler, dalam Billingham, 1987). 
Kekerasan dalam pacaran di Indonesia paling banyak terjadi pada perempuan dengan rentang usia 25-40 tahun (Indraswari, dalam Erdianto, 2016), di mana individu dengan rentang usia tersebut sedang menempuh tahapan psikososial intimasi dan isolasi (Erikson, dalam Papalia, Olds, \& Feldman, 2007). Pada tahapan tersebut, setiap individu memiliki tantangan untuk menciptakan hubungan yang mendalam dengan orang lain, misalnya tantangan untuk dapat menyelesaikan konflik dengan sehat. Keberhasilan pada tahapan ini akan memberikan virtue, yakni love (cinta kasih) pada individu tersebut, sehingga ia dapat memiliki hubungan yang penuh komitmen dan mendalam dengan sesamanya. Sementara itu, individu yang gagal pada tahapan ini akan cenderung memiliki kesulitan dalam membangun komitmen dan cenderung terisolasi. Oleh sebab itu, sangat penting bagi individu untuk dapat menciptakan hubungan dekat dengan sesamanya, baik hubungan pertemanan maupun romantis. Salah satu bagian yang dikenal sebagai bentuk dari hubungan romantis ialah hubungan pacaran (Erikson, dalam Cherry, 2017).

\section{Rasa Percaya dalam Hubungan Romantis (Trust in Close Relationship)}

Berbagai macam komponen diperlukan individu untuk dapat mengelola hubungan romantis yang sehat. Rasa percaya dalam hubungan romantis diketahui sebagai salah satu komponen yang berperan sebagai fondasi dalam keberhasilan suatu hubungan romantis (Regan, Kocan, \& Whitlock, dalam Simpson, 2007a). Rasa percaya dalam hubungan romantis berfungsi untuk menciptakan hubungan yang sehat dan penuh rasa aman (Simpson, 2007a; Holmes \& Rempel, 1989; Larzelere \& Huston, 1980). Dengan adanya rasa aman yang ditimbulkan oleh kepercayaaan dengan pasangan, individu dapat lebih leluasa mengungkapkan perasaan maupun rencana dalam hidupnya pada pasangan (Stinnett \&Walters, dalam Larzelere \& Huston, 1980).

Secara umum, rasa percaya dalam hubungan romantis disebut sebagai keyakinan individu terhadap pasangan, bahwa pasangan akan berlaku sesuai dengan yang diharapkannya (Rempel, Holmes, \& Zanna, 1985). Sementara itu, Larzelere dan Huston (1980) mendefinisikan rasa percaya dalam hubungan romantis sebagai keyakinan individu terhadap pasangan, bahwa pasangan bersikap jujur dan penuh kebajikan. Berdasarkan kedua definisi tersebut, dapat dikatakan bahwa rasa percaya dalam hubungan romantis ialah keyakinan bahwa pasangan berlaku sesuai dengan yang diharapkan, penuh kebajikan, dan jujur. Rasa percaya dikenal sebagai elemen yang dapat menciptakan hubungan yang sehat (Erikson, dalam Lewicki, McAllister, \& Bies, 1998). Selain itu, diketahui pula bahwa rasa percaya berperan sebagai fondasi dan kunci kesuksesan dalam hubungan interpersonal yang sehat (Erikson, dalam Lewicki, McAllister, \& Bies, 1998; Holmes \& Rempel, dalam Feldman, 
Cauffman, Jensen, \& Arnett, 2000). Apabila rasa percaya tidak ada, maka sulit bagi pasangan untuk saling terikat, memberi, dan berani untuk mengambil resiko (Mizrahi, 2002).

Terdapat rangkaian faktor yang dapat memengaruhi tinggi atau rendahnya rasa percaya seseorang, di antaranya adalah kepribadian big five personalities (Miller, 2015), konsep diri (selfconcept) (Simpson, 2007b), keberhargaan diri (self-esteem), perasaan aman (personal security) (Simpson, 2007b; Holmes \& Rempel, 1989), pola keterikatan (attachment styles) (Mikulincer \& Shaver, 2007), perkembangan psikososial trust vs mistrust saat kecil (Erikson, dalam Miller, 2015; Erikson, dalam Holmes \& Rempel, 1989), serta pengalaman di masa lalu (Kingdon \& Stines, 2018). Rasa percaya seseorang dapat meningkat apabila individu yakin bahwa pasangan memiliki komitmen, intensi, dan motivasi yang penuh kebajikan (benevolent).

Rempel dkk., (1985) mengemukakan tiga komponen yang terdapat pada rasa percaya dalam hubungan romantis di antaranya adalah prediktabilitas (predictability), ketergatungan (dependability), dan keyakinan (faith). Prediktabilitas merupakan keyakinan bahwa perilaku pasangan konsisten atau stabil, sehingga dapat diprediksikan. Ketergantungan merupakan keyakinan bahwa pasangan jujur dan dapat diandalkan, sehingga kualitas pasangan dapat dievaluasi oleh individu. Sedangkan, keyakinan didefinisikan sebagai keyakinan individu bahwa pasangan dapat berlaku sesuai dengan yang diyakininya (peduli dan responsif), sehingga individu siap untuk menghadapi situasi yang tidak dapat diprediksikan. Ketiga komponen tersebut dikonstruksikan ke dalam alat ukur trust scale yang dikemukakan oleh ketiga peneliti tersebut. Alat ukur ini bertujuan untuk mengukur rasa percaya (trust) individu terhadap pasangan dalam menaungi hubungan romantis. Melalui penelitian tersebut, Rempel dkk., (1985) menemukan bahwa perempuan berkorelasi terhadap ketiga komponen rasa percaya dalam hubungan romantis secara kuat. Sedangkan, pada pria hanya ditemukan korelasi yang lemah. Menurut ketiganya, hasil tersebut dapat diartikan bahwa perempuan cenderung memiliki pandangan yang integratif terhadap rasa percaya. Perempuan memiliki pandangan bahwa rasa percaya tidak hanya dilandasi oleh keyakinan belaka. Kualitas pasangan (ketergantungan) serta stabilitas perilaku pasangan (prediktabilitas) juga dianggap memiliki peranan penting dalam membentuk rasa percaya seseorang.

\section{Tujuan Penelitian}

Berdasarkan uraian di atas, dapat diketahui bahwa rasa percaya dalam hubungan romantis dan kekerasan dalam pacaran memiliki peranan penting dalam menentukan kualitas hubungan pacaran. Oleh sebab itu, penelitian ini bertujuan untuk melihat apakah terdapat hubungan yang 
signifikan antara rasa percaya dalam hubungan romantis dan kekerasan dalam pacaran pada perempuan dewasa muda di Jakarta. Hipotesis penelitian ini ialah terdapat hubungan yang signifikan antara rasa percaya dalam hubungan romantis dan kekerasan dalam pacaran pada perempuan dewasa muda di Jakarta.

\section{METODE}

\section{Partisipan}

Partisipan dalam penelitian ini ialah 165 perempuan dewasa muda (berusia 20-40 tahun) yang sedang menjalani hubungan pacaran heteroseksual minimal satu tahun lamanya dan berdomisili di Jakarta. Teknik sampling yang digunakan ialah purposive sampling dengan pertimbangan adanya karakteristik khusus pada individu yang dibutuhkan untuk penelitian. Partisipan diminta untuk mengisi kuesioner dalam bentuk hardcopy maupun online (Google Form).

\section{Desain}

Penelitian ini menggunakan metode kuantitatif dengan teknik korelasi untuk menghubungkan kedua variabel, baik rasa percaya dalam hubungan romantis (sebagai variabel pertama) dan kekerasan dalam pacaran (sebagai variabel kedua).

\section{Instrumen}

Alat ukur yang digunakan dalam penelitian ini merupakan Trust Scale (Rempel dkk., 1985) serta The Revised Conflict Tactics Scale (CTS2) yang telah diadaptasi di Indonesia (Putri, 2012).

Trust Scale bertujuan untuk mengukur kepercayaan individu terhadap pasangan dalam menjalani hubungan romantis. Trust scale terdiri dari 17 butir, dengan 13 pernyataan non-reverse serta empat pernyataan reverse. Komponen prediktabilitas berjumlah lima butir (dengan empat butir pernyataan reverse), komponen ketergantungan berjumlah lima butir, sedangkan komponen keyakinan berjumlah tujuh butir. Alat ukur tersebut berbasis skala Likert yang memiliki rentang dari 1 - 7 (seven-point scale). Responden diminta untuk memilih skala dari sangat tidak setuju (1) hingga sangat setuju (7). Perhitungan skor dari alat ukur ini dilakukan dengan cara menjumlahkan skor total dari ketiga komponen tersebut.

Instrumen ke dua ialah The Revised Conflict Tactics Scale (CTS2) yang telah diadaptasi (Putri, 2012). CTS2 bertujuan untuk mengukur kekerasan dalam relasi hubungan romantis (baik 
hubungan pacaran hingga hubungan pernikahan). CTS2 memiliki model partner to partner, di mana partisipan diminta untuk memberi respons tentang bagaimana perilakunya terhadap pasangan (sebagai pelaku) dan perilaku pasangan terhadapnya (sebagai korban) dalam menyelesaikan suatu konflik yang muncul dalam hubungan romantis selama satu tahun terakhir. Alat ukur ini berskala Likert dengan rentang 0 (tidak pernah) hingga 4 (sangat sering) dan terdiri dari empat dimensi. Keempat dimensi tersebut merupakan negosiasi (negotiation), agresi psikologis (psychological aggression), kekerasan fisik (physical assault), dan kekerasan seksual (sexual coercion).

Uji coba terhadap 50 partisipan dilakukan dengan kriteria yang sesuai dengan karakteristik penelitian. Berdasarkan hasil dari uji coba tersebut, ditemukan bahwa trust scale memiliki nilai reliabilitas Cronbach's Alpha sebesar .872. Selanjutnya, nilai reliabilitas Cronbach's Alpha pada ketiga komponen rasa percaya dalam hubungan romantis, yakni prediktabilitas, ketergantungan, dan keyakinan ialah $.710, .705$, dan .846 berturut-turut.

Hasil dari uji coba terhadap alat ukur CTS2 menunjukan rentang nilai reliabilitas sebesar $\alpha=$ .904 setelah mengeliminasi sepuluh butir yang nilai validitasnya di bawah kriteria yang ditetapkan $(r<.02)$. Nilai reliabilitas pada masing-masing dimensi CTS2 ialah, $\alpha=.881$ (negosiasi), $\alpha=.887$ (agresi psikologis), $\alpha=.822$ (kekerasan fisik), dan $\alpha=.655$ (kekerasan seksual).

\section{Prosedur}

Setelah menentukan variabel dan tujuan penelitian, peneliti menentukan alat ukur yaitu Trust Scale oleh Rempel dkk., (1985) serta The Revised Conflict Tactics Scale atau CTS2 oleh Straus dkk., (1996) yang telah diadaptasi di Indonesia oleh Putri (2012) sebagai bagian dari instrumen penelitian. Peneliti melakukan penerjemahan untuk Trust Scale dari Bahasa Inggris ke Bahasa Indonesia dan melakukan back translation. Selanjutnya Trust Scale diproses melalui validitas muka (face validity) oleh dua akademisi di bidang psikologi.

Berkas kuesioner mencakup lembar persetujuan (informed consent), data demografis, kedua alat ukur penelitian (Trust Scale dan The Revised Conflict Tactics Scale atau CTS2 yang telah diadaptasi). Kuesioner ini dibagikan pada partisipan yang memiliki karakteristik yang sesuai dengan penelitian ini. Pada langkah akhir, peneliti mengumpulkan data yang diperoleh untuk melakukan analisis statistik guna menguji hipotesis. 


\section{Teknik Analisis}

Kolmogorov Smirnov digunakan untuk menguji normalitas, internal consistency cronbach's alpha untuk menguji reliabilitas, serta uji korelasi Spearman Correlation (jika persebaran data tidak normal) atau Pearson Correlation (jika persebaran data normal) untuk menguji hipotesis penelitian.

\section{ANALISIS DAN HASIL}

\section{Profil Partisipan}

Terkumpul sebanyak 171 kuesioner (terdiri dari 13 kuesioner hardcopy dan 158 kuesioner online atau googleform) selama periode pengumpulan data. Enam kuesioner tidak dapat digunakan, karena tidak sesuai dengan karakteristik penelitian yang telah ditentukan (terdapat dua partisipan yang sedang menjalani hubungan pacaran di bawah satu tahun, dua pastisipan berusia 19 tahun, dan dua partisipan lainnya tidak mengisi data demografis secara lengkap). Dengan demikian, sebanyak 165 kuesioner dari perempuan dewasa muda yang sesuai dengan karakteristik penelitian ini diterima untuk dianalisis secara statistika. Profil demografis partisipan ditunjukkan dalam Tabel 1. Mayoritas partisipan adalah mahasiswa, berdomisili di wilayah Jakarta Barat, memiliki pendidikan terakhir SMA, dan bersuku Tionghoa.

Tabel 1.

Data Demografis

\begin{tabular}{|c|c|c|c|c|c|}
\hline \multicolumn{2}{|c|}{ Karakteristik } & \multirow{2}{*}{$\frac{\text { Mean }}{22}$} & \multirow{2}{*}{$\frac{\text { Min }}{20}$} & \multirow{2}{*}{$\frac{\operatorname{Max}}{30}$} & \multirow{2}{*}{$\begin{array}{c}\text { Std. Deviasi } \\
1.97\end{array}$} \\
\hline Usia & 20-30 tahun & & & & \\
\hline Usia Pasangan & $16-50$ tahun & 23.5 & 16 & 50 & 3.48 \\
\hline Lama Hubungan Pacaran & 1-9 tahun & 2.5 & 1 & 9 & 1.95 \\
\hline
\end{tabular}

\section{Uji Normalitas}

Uji normalitas Kolmogorov-Smirnov menunjukkan bahwa variabel rasa percaya dalam hubungan romantis disebut normal $(p=.200)$ dan variabel kekerasan dalam pacaran dinyatakan tidak normal $(p=.000)$. Melihat adanya variabel yang tidak normal, peneliti menggunakan teknik uji korelasi Spearman Rho untuk menghubungkan kedua variabel. 


\section{Korelasi antara Rasa Percaya dalam Hubungan Romantis dan Kekerasan dalam Pacaran}

Hasil uji hipotesis menunjukkan bahwa rasa percaya dalam hubungan romantis dan kekerasan dalam pacaran memiliki korelasi negatif yang signifikan $\left(r_{s}=-.528, p=.000\right)$. Selain melakukan uji korelasi antar variabel, peneliti juga melakukan uji korelasi antar masing-masing komponen dan dimensi variabel. Tabel 2 menunjukkan matriks korelasi antar variabel, maupun komponen, dan dimensi variabel.

Tabel 2.

Matriks Korelasi antar Dimensi dan Komponen Variabel

\begin{tabular}{|c|c|c|c|c|c|c|c|c|c|}
\hline Variabel & 1 & 2 & 3 & 4 & 5 & 6 & 7 & 8 & 9 \\
\hline 1. Rasa Percaya & 1 & & & & & & & & \\
\hline 2. Predictability & $.787^{* *}$ & 1 & & & & & & & \\
\hline 3. Dependability & $.841^{* *}$ & $.471^{* *}$ & 1 & & & & & & \\
\hline 4. Faith & $.866^{* *}$ & $.490^{* *}$ & $.648^{* *}$ & 1 & & & & & \\
\hline $\begin{array}{l}\text { 5. Kekerasan } \\
\text { dalam Pacaran }\end{array}$ & $-.528^{* *}$ & $-.490^{* *}$ & $-.398^{* *}$ & $-.438^{* *}$ & 1 & & & & \\
\hline $\begin{array}{l}\text { 6. Negosiasi } \\
\text { 7. Agresi }\end{array}$ & $.515^{* *}$ & $.423^{* *}$ & $.375^{* *}$ & $.480^{* *}$ & $-.613^{* *}$ & 1 & & & \\
\hline $\begin{array}{l}\text { Psikologis } \\
\text { 8. Kekerasan }\end{array}$ & $-.327^{* *}$ & $-.344^{* *}$ & $-.247^{* *}$ & $-.240^{* *}$ & $.798^{* *}$ & -.147 & 1 & & \\
\hline $\begin{array}{l}\text { Fisik } \\
\text { 9. Kekerasan }\end{array}$ & $-.264^{* *}$ & $-.257^{* *}$ & $-.200^{* *}$ & $-.196^{*}$ & $.622^{* *}$ & $-.162^{*}$ & $.480^{* *}$ & 1 & \\
\hline Seksual & $-.373^{* *}$ & $-.273^{* *}$ & $-.318^{* *}$ & $-.374^{* *}$ & $.504^{* *}$ & $-.250^{* *}$ & $.386^{* *}$ & $.353^{* *}$ & 1 \\
\hline
\end{tabular}

\section{Analisis Data Tambahan}

Menambahkan hasil penelitian, peneliti juga menemukan korelasi yang signifikan antara faktor usia dengan rasa percaya dalam hubungan romantis maupun kekerasan dalam pacaran. Pertama, faktor usia ditemukan memiliki korelasi yang positif dengan rasa percaya $\left(r_{s}=.209, p=\right.$ .007). Artinya, semakin bertambahnya usia individu, maka semakin tinggi pula rasa percayanya, dan sebaliknya. Faktor ke dua, usia ditemukan berkorelasi negatif dengan variabel kekerasan dalam pacaran $\left(r_{s}=-.190, p=.015\right)$. Artinya, semakin bertambah usia individu, maka semakin rendah frekuensi kekerasan dalam pacaran, dan berlaku sebaliknya. Ke tiga, peneliti menemukan adanya korelasi positif yang signifikan antar jenis-jenis kekerasan dalam pacaran. Artinya, apabila salah satu frekuensi jenis kekerasan dalam pacaran tinggi, maka semakin tinggi pula frekuensi jenis kekerasan dalam pacaran lainnya. Sementara, pada hasil analisis data tambahan yang ke empat, ditemukan adanya korelasi positif yang signifikan antara faktor perempuan sebagai pelaku dan korban kekerasan dalam pacaran $\left(r_{s}=.746, p=.000\right)$. Melalui hasil tersebut, dapat diartikan bahwa 
semakin tinggi frekuensi perilaku kekerasan yang didapatkan, maka semakin tinggi pula frekuensinya untuk memaparkan kekerasan pada pasangannya, dan sebaliknya.

\section{DISKUSI}

Selain menemukan adanya hubungan yang signifikan antara rasa percaya dalam hubungan romantis, peneliti juga menemukan adanya korelasi yang signifikan antara ketiga komponen rasa percaya (prediktabilitas, ketergantungan, dan keyakinan) dengan variabel kekerasan dalam pacaran. Begitu pula dengan keempat dimensi kekerasan dalam pacaran yang ditemukan berkorelasi dengan rasa percaya pada hubungan romantis. Menurut Straus dkk., (1996), kekerasan dalam pacaran seringkali muncul apabila terdapat ketegangan atau konflik yang memuncak. Saat menghadapi konflik, kekerasan psikologis, fisik, maupun seksual cenderung dipakai sebagai media untuk resolusi konflik dalam hubungan romantis. Sementara itu, negosiasi diperlukan bagi individu maupun pasangan untuk menyelesaikan konflik secara sehat. Dengan kata lain, segala metode yang dipakai oleh kedua pihak menentukan kualitas hubungan romantis itu sendiri (Kim dkk., 2015).

Berdasarkan uji korelasi antara variabel rasa percaya dalam hubungan romantis dengan dimensi negosiasi, dapat terlihat bahwa negosiasi dan rasa percaya dalam hubungan romantis memiliki keterkaitan yang signifikan. Artinya, semakin tinggi frekuesi negosiasi dalam menyelesaikan suatu konflik, maka semakin tinggi pula rasa percaya individu terhadap pasangannya dan berlaku sebaliknya. Hasil tersebut sesuai dengan pernyataan oleh Holmes dan Rempel (1989) yang menyatakan bahwa penting bagi individu dan pasangan dalam melakukan diskusi untuk menyelesaikan konflik hubungan romantis. Diskusi dalam menyelesaikan konflik dapat memberikan kesempatan bagi kedua belah pihak untuk menyampaikan perasaan, mencoba untuk saling memahami pandangan sama lain, sehingga individu maupun pasangan dapat menyelesaikan permasalahan yang memuncak secara lebih objektif dan konstruktif (Holmes \& Rempel, 1989; Straus dkk., 1996).

Lebih dalam lagi, rasa percaya seseorang dapat dilihat dalam kecenderungannya untuk menyelesaikan konflik dengan pasangannya. Seseorang dengan rasa percaya yang tinggi cenderung bersikap toleran dan positif. Individu dengan karakteristik tersebut memiliki keyakinan bahwa pasangan akan bersikap penuh kasih sayang (compassionate) dan penuh perhatian (considerate). Dengan demikian, individu dengan nilai rasa percaya yang tinggi cenderung menggunakan diskusi atau negosiasi sebagai teknik penyelesaian konflik hubungan romantis. Berbeda dengan individu 
yang memiliki nilai rasa percaya yang tinggi, individu dengan rasa percaya yang rendah cenderung yakin bahwa pasangan tidak akan berperilaku yang sesuai dengan harapannya, sehingga seseorang yang memiliki karakteristik ini akan mempertanyakan apakah pasangannya peduli dan mencintainya (Rempel \& Holmes, 1986; Holmes \& Rempel, 1989). Tinggi atau rendahnya rasa percaya bergantung pada sikap dan perilaku pasangan, sehingga nantinya individu dapat mengevaluasi kualitas pasangan, apakah kualitas pasangan baik atau tidak, sehingga layak untuk dipertahankan (Holmes \& Rempel, 1989). Apablila pasangan dinilai memiliki komitmen serta memiliki motivasi maupun intensi yang baik (benevolent), maka rasa percaya individu akan menguat (Simpson, 2007a).

Pada jenis kekerasan, kekerasan psikologis memiliki korelasi yang negatif dan signifikan jika dihubungkan dengan variabel rasa percaya dalam hubungan romantis. Hasil tersebut sesuai dengan Murray (dalam Simpson, 2007a) yang menyatakan bahwa individu yang memiliki rasa percaya yang rendah berpotensi untuk melakukan kekerasan psikologis, misalnya menghancurkan barang pasangan dan meneriaki pasangan saat menyelesaikan konflik dengan pasangannya. Dapat dijelaskan bahwa hal ini disebabkan oleh kecenderungan individu untuk bersikap defensif, di mana hal tersebut didorong oleh ketidakyakinan indvidu terhadap kualitas pasangannya. Oleh sebab itu, agresi dan perilaku maladaptif cenderung dipakai sebagai metode penyelesaian konflik (Gottman, dalam Kim dkk., 2015; Simpson, 2007a).

Kekerasan seksual juga ditemukan berkorelasi negatif dan signifikan dengan variabel rasa percaya dalam hubungan romantis. Hasil korelasi ini merupakan yang tertinggi jika dibandingkan dengan jenis kekerasan psikologis dan fisik. Artinya, kekerasan seksual memiliki peranan lebih terhadap tinggi atau rendahnya rasa percaya seseorang. Hasil penelitian ini sesuai dengan studi Eshelman dan Levendosky (2012) yang menyebutkan kekerasan seksual sebagai jenis kekerasan yang tertinggi. Menurut mereka, kekerasan seksual memiliki dampak yang lebih besar jika dibandingkan dengan jenis kekerasan lainnya. Berkaitan dengan isu rasa percaya dalam hubungan romantis, Collibee dan Furman (2014) menjelaskan bahwa korban kekerasan seksual dari pasangannya cenderung mempersepsikan bahwa sikap dan perilaku pasangan merupakan manifestasi dari intensi negatif pasangan. Hal ini didorong oleh perasaan sakit korban paska mengalami kekerasan dari pasangan (Vangelisti, Young, Carpenter-Theune, \& Alexander, dalam Fitness \& Warburton, 2010), sehingga semakin banyak interaksi negatif yang terjadi dalam hubungan romantis, maka semakin sering pula individu untuk mempersepsikan perilaku negatif yang akan diterima di kemudian hari. 
Selain memperoleh temuan utama, penelitian ini juga menghasilkan sejumlah temuan tambahan. Peneliti menemukan bahwa usia individu memiliki korelasi positif yang signifikan dengan rasa percaya dalam hubungan romantis serta berkorelasi negatif dengan kekerasan dalam pacaran. Temuan ini selaras dengan hasil penelitian yang Poulin dan Haase (2015). Menurut kedua peneliti tersebut, korelasi positif antara usia dengan rasa percaya dapat dilihat dari kecenderungan individu dalam menilai dan melihat situasi secara lebih positif, di mana individu yang berusia lebih tua cenderung lebih mudah memaafkan, sehingga dapat menyikapi konflik dengan lebih bijaksana (Poulin \& Haase, 2015). Sedangkan, korelasi negatif yang signifikan antara usia dengan kekerasan dalam pacaran dapat dilihat oleh semakin matangnya individu dalam membina hubungan dekat yang membuat mereka matang dalam menyelesaikan konflik dan menentukan pasangan (Giordano dkk., dalam Johnson dkk., 2015). Rasa tanggung jawab pada individu juga semakin meningkat seiring bertambahnya usia, sehingga kecenderungan untuk terikat dengan perilaku ilegal seperti kekerasan disebut lebih sedikit jika dibandingkan dengan individu yang berusia lebih muda (Massoglia \& Uggen, dalam Johnson dkk., 2015).

Temuan lainnya dalam penelitian ini menunjukkan bahwa ketiga jenis kekerasan diketahui berkorelasi secara signifikan antar satu sama lain. Temuan ini sesuai dengan penelitian Straus dkk., (1996) dan Wandansari (2013) yang menemukan adanya korelasi positif antara kekerasan fisik dan psikologis. Menurut Berkowitz (dalam Straus dkk., 1996) dan O’Leary \& Maiuro (dalam Capaldi dkk., 2012), sangat memungkinkan bagi individu yang sedang berseteru dengan pasangannya dan menggunakan agresi verbal untuk menggunakan agresi dalam bentuk lainnya terhadap pasangannya (misalnya: kekerasan fisik). Korelasi positif antara kekerasan fisik dan psikologis dengan kekerasan seksual juga sesuai dengan asumsi yang dikemukakan oleh Straus dkk., (1996). Menurutnya, apabila frekuensi kekerasan fisik dan psikologis tinggi, maka sangat memungkinkan bagi kekerasan seksual untuk muncul.

Temuan berikutnya dalam penelitian ini ialah semakin tinggi frekuesi kekerasan yang dialami perempuan dewasa muda, maka semakin tinggi pula frekuensi kekerasan dalam pacaran yang akan dipaparkan pada pasangannya. Hasil tersebut sesuai dengan teori Gelles dan Straus (dalam Straus dkk., 1996) yang menjelaskan bahwa salah satu alasan berhentinya perilaku kekerasan dalam hubungan pacaran ialah berhentinya tindak kekerasan yang dipaparkan dari salah satu pihak. Menurut Kernsmith (dalam Straus, 2010), kecenderungan perempuan dalam memaparkan perilaku kekerasan dilandasi oleh alasan atau motivasi mengekspresikan rasa marah, membalaskan kekerasan yang diterima dari pasangan, serta memberikan hukuman atas perilaku 
pasangan yang tidak diinginkan. Selain itu, dijelaskan juga bahwa mayoritas perempuan yang memaparkan kekerasan terhadap pasangan didorong oleh rasa frustrasi, cemburu, dan amarah yang intens (Pearson, dalam Straus, 2010). Dengan kata lain, paparan perilaku agresi disebabkan oleh perasaan yang intens dan tidak dihargai oleh pasangan, sehingga individu menginginkan untuk meraih kontrol kembali dari pasangannya (Jolly \& Connolly, 2016).

Penelitian ini memiliki keterbatasan pada partisipan yang berdampak generalisasi hasil. Subjek penelitian yang berhasil diraih pada penelitian ini hanya berusia 20 sampai 30 tahun, sedangkan penelitian ini memiliki rencana awal untuk memperoleh subjek dengan kriteria 20 sampai 40 tahun. Oleh karena itu, hasil hanya dapat digeneralisasikan pada kelompok dengan rentang usia 20 sampai 30 tahun.

\section{SIMPULAN DAN SARAN}

\section{Simpulan}

Penelitian ini bertujuan untuk mengetahui apakah terdapat hubungan yang signifikan antara rasa percaya dalam hubungan romantis dan kekerasan dalam pacaran pada perempuan dewasa muda di Jakarta. Hasil penelitian menunjukkan adanya hubungan negatif yang signifikan antara rasa percaya dalam hubungan romantis dan kekerasan dalam pacaran pada perempuan dewasa muda di Jakarta. Artinya, semakin tinggi rasa percaya individu terhadap pasangannya, maka semakin rendah frekuensi kekerasan dalam pacaran yang dialami oleh individu (dan berlaku sebaliknya).

\section{Saran Teoretis}

Peneliti memberikan beberapa saran untuk peneliti selanjutnya yang tertarik dengan variabel rasa percaya dalam hubungan romantis dan kekerasan dalam pacaran. Pertama, diharapkan agar penelitian dapat diteruskan dengan menggunakan metode penelitian kualitatif agar kedua variabel tersebut dapat dieksplorasi dan dipahami lebih dalam lagi. Saran kedua, penelitian ini dapat dilanjutkan pada penelitian yang berbasis dyadic atau penelitian yang memerlukan pasangan sebagai partisipan (partner to partner study). Saran ketiga, peneliti juga dapat meneliti variabel rasa percaya dalam hubungan romantis dengan partisipan yang memiliki latar belakang yang bervariasi, misalnya jenis pengalaman kekerasan di masa lampau. 


\section{Saran Praktis}

Bagi individu dewasa muda, penelitian ini diharapkan dapat membuat individu semakin mengerti akan pentingnya rasa percaya dalam membangun hubungan romantis. Rasa percaya dapat ditingkatkan dengan cara menggunakan metode penyelesaian konflik yang tepat dan sehat saat konflik, seperti dengan cara negosiasi. Negosiasi dapat diterapkan dengan cara melakukan diskusi dengan pasangan saat menyelesaikan suatu konflik. Adanya diskusi dapat memberikan kesempatan bagi masing-masing pihak untuk saling bertukar pikiran dan perasaan, sehingga kedua pihak dapat saling mengerti dan mencari solusi secara lebih konstruktif. Selain itu, bagi pekerja sosial yang memiliki ketertarikan di isu kekerasan dalam pacaran, dapat mengerti bahwa kekerasan dalam pacaran cenderung terjadi pada individu yang berusia lebih muda. Dengan demikian, psikoedukasi mengenai hubungan pacaran yang sehat dapat ditekankan pada individu sejak dini.

\section{UCAPAN TERIMA KASIH}

Peneliti mengucapkan terima kasih kepada Kevin Djasa dan Julian Adrian Halim selaku pihak yang telah membantu peneliti dalam menerjemahkan alat ukur Trust Scale.

\section{REFERENSI}

American Psychological Association. (2002). Intimate partner abuse and relationship violence. Ditemu kembali dari http://apa.org/about/division/activities/partner-abuse.pdf.

Billingham, R. E. (1987). Courtship violence: The patterns of conflict resolution strategies across seven levels of emotional commitment. Journal of Family Relations, 36(3), 283-289.

Capaldi, D. M., Knoble, M. B., Shortt, J. W., \& Kim, H. K. (2012). A systematic review of risk factors for intimate partner violence. Journal of Partner Abuse, 3(2), 231-280. doi: 10.1891/1946-6560.3.2.231.

Chan, K. L., Straus, M. A., Brownridge, D. A., Tiwari, A., \& Leung, W. C. (2008). Prevalence of dating partner violence and suicidal ideation among male and female university students worldwide. Journal of Midwifery \& Women's Health, 53(6), 529-537. doi: 10.1016/j.jmwh.2008.04.016.

Cherry, K. (2017). Intimacy vs Isolation: Psychological stage 6 forming intimate relationships with others. Ditemu kembali dari https://www.verywell.com/intimacy-versus-isolation-2795739. 
Collibee, C., \& Furman W. (2014). Impact of sexual coercion on romantic experiences of adolescents and young adults. Journal of Sexual Behavior, 43, 1431-1441. doi: 10.107/s10508-013-0256-0.

Databoks. (2017). Kekerasan terhadap perempuan paling tinggi di Jakarta. Ditemu kembali dari http://databoks.katadata.co.id/datapublish/2017/03/09/kekerasan-terhadap-perempuan-didki-jakarta-paling-tinggi.

Erdianto, K. (2016). Angka kekerasan dalam pacaran tinggi, tetapi UU belum melindungi. Ditemu kembali dari http://nasional.kompas.com/read/2016/03/08/07513391/Angka.Kekerasan. dalam.Pacaran.Tinggi.tetapi.UU.Belum.Melindungi.

Eshelman, L. R., \& Levendosky, A. (2012). Dating violence: Mental health consequences based on type of abuse. Journal of Violence and Victims, 27(2), 215-228. doi: 10.1891/08866708.27.2.215.

Feldman, S. S., Cauffman, E., Jensen, L. A., \& Arnett, J. J. (2000). The (un)acceptability of betrayal: A study of college students' evaluations of sexual betrayal by a romantic partner and betrayal of a friend's confidence. Journal of Youth and Adolescence, 29(4), 499-523.

Few, A. L., \& Rosen, K. H. (2005). Victims of chronic dating violence: How women's vulnerablilities link to their decisions to stay. Journal of Family Relations, 54(2), 265-279.

Firestone, W. R., \& Catlett, J. (2003). Fear of Intimacy. Washington, DC: American Psychological Association.

Fitness, J., \& Warburton, W. (2010). Thinking the unthinkable: Cognitive appraisals and hurt feelings. Dalam A. L. Vangelisti (Ed.), Feeling hurt in close relationships (Vol. 3, hlm. 3449). New York, NY: Cambridge University Press.

Himawan, K. K. (2017). Jealousy and relationship satisfaction among Indonesian dating adults. PsyCh Journal, 6(4), 328-329. doi: 10.1002/pchj.195.

Holmes, J. G., \& Rempel, J. K. (1989). Trust in close relationships. Dalam C. Hendrick (Ed.), Close relationships: Review of personality and social psychology (Vol. 10, hlm. 187-220). Newbury Park, CA: Sage Publications.

Howe, F. (2002). The value of intimate relationships and the challenge of conflict. Journal of Invitational Theory and Practice, 8, 15-26.

Johnson, W. L., Giordano, P. C., Manning, W. D., \& Longmore, M. A. (2015). The age-IPV curve: Changes in the perpetration of intimate partner violence during adolescence and young adulthood. Journal of Youth Adolescence, 44(3), 708-726. doi: 10.1007/s10964-014-0158-z. 
Jolly, L. E., \& Connolly, J. (2016). Dating violence among high-risk young women: A systematic review using quantitative and qualitative methods. Journal of Behavioral Science, 6(7), 116. doi: 10.3390/bs6010007.

Kaukinen, C., Buchanan, L., \& Gover, A. R. (2015). Child abuse and the experience of violence in college dating relationships: Examining the moderating effect of gender and race. Journal of Family Violence, 30(8), 1079-1092. doi: 10.1007/s10896-015-9731-9.

Kim, J. S., Weisberg, Y. J., Simpson, J. A., Orina, M. M., Farrell, A. K., \& Johnson, W. F. (2015). Ruining it for both of us: The disruptive role of low-trust partners on conflict resolution in romantic relationships. Journal of Social Cognition, 33(5), 520-542.

Kingdon, M., \& Stines, S. (2018). Abuse or survivors of abuse. Ditemu kembali dari http://www.goodtherapy.org/learn-about-therapy/issues/abuse.

Larzelere, R. E., \& Huston, T. L. (1980). The dyadic trust scale: Toward understanding interpersonal trust in close relationships. Journal of Marriage and Family, 42(3), 595-604.

Lee, J., Pomeroy, E. C., \& Bohman, T. M. (2007). Intimate partner violence and psychological health in a sample of asian and caucasian women: The roles of social support and coping. Journal of Family Violence, 22(8), 709-720. doi: 10.1007/s10896-007-9119-6.

Lewicki, R. J., McAllister, D. J., \& Bies, R. J. (1998). Trust and distrust: New relationships and realities. Journal of Academy Management Review, 22(3), 438-458.

Komisi Nasional Perempuan. (2015). Lembar fakta Catatan Tahunan (CATAHU) 2014, kekerasan terhadap perempuan: Negara segera putus impunitas pelaku. Ditemu kembali dari http://www.komnasperempuan.go.id/wp-content/uploads/2015/03/Lembar-Fakta-CatatanTahunan-CATAHU-Komnas-Perempuan-Tahun-2014.pdf.

Komisi Nasional Perempuan. (2016). Lembar fakta Catatan Tahunan (CATAHU) 2016, kekerasan terhadap perempuan meluas: Mendesak negara hadir hentikan kekerasan terhadap perempuan di ranah domestik, komunitas dan negara. Ditemu kembali dari http://www.komnasperempuan.go.id/wp-content/uploads/2016/03/Lembar-Fakta-CatatanTahunan-_CATAHU_-Komnas-Perempuan-2016.pdf.

Mikulincer, M., \& Shaver, P. R. (2007). Attachment in adulthood: Structure, dynamics and change (1st ed.). New York, NY: The Guilford Press.

Miller, R. S. (2015). Intimate relationships (7th ed.). New York, NY: McGraw-Hill.

Mizrahi, T. (2002). How can you learn to trust again?. Ditemu kembali dari https://www.psychologytoday.com/articles/200203/how-can-you-learn-trust-again. 
National Center for Victims of Crime. (2012). Bulletins for Teens: Dating Violence. Ditemu kembali dari https://victimsofcrime.org/help-for-crime-victims/get-help-bulletins-for-crimevictims/bulletins-for-teens/dating-violence.

Papalia, D. E., Olds, S. W., \& Feldman R. D. (2007). Human Development (10th ed). New York, NY: McGraw-Hill.

Poulin, M. J., \& Haase, C. M. (2015). Growing to trust: Evidence that trust increases and sustains well-being across the life span. Journal of Social Psychological and Personality Science, 6(6), 614-621. doi: 10.1177/1948550615574301.

Putri, Y. Z. (2012). Hubungan antara kekerasan dalam pacaran dan self-esteem pada perempuan dewasa muda (Bentuk literatur tidak dipublikasi). Ditemu kembali dari http://lib.ui.ac.id/naskahringkas/2015-08/S44811-yuanita\%20zandy\%20putri.

Rempel, J. K., Holmes, J. G., \& Zanna, M. P. (1985). Trust in close relationships. Journal of Personality and Social Psychology, 49(1), 95-112.

Rempel, J. K., \& Holmes, J. G. (1986). How do i trust thee?. Psychology Today, 28-34.

Ross, J. (2015). The role of power in conflict in adult close relationships (Bentuk literatur tidak dipublikasi). Ditemu kembali dari http://repository.cmu.edu/cgi/viewcontent.cgi?article=1244\&context=hsshonors.

Simpson, J. A. (2007a). Foundations of interpersonal trust. Dalam A. W. Kruglanski \& E. T. Higgins (Eds.), Social psychology: Handbook of basic principles (2nd ed., hlm. 587-607). New York, NY: Guilford.

Simpson, J. A. (2007b). Psychological foundations of trust. Journal of Association for Psychological Science, 16(5), 264-268.

Straus, M. A., Hamby, S. L., McCoy, S. B., \& Sugarman, D. B. (1996). The revised conflict tactics scales (CTS2): Development and preliminary psychometric data. Journal of Family Issues, 17(3), 283-316. doi: 10.1177/019251396017003001.

Straus, M. A., \& Douglas, E. M. (2004). A short form of the revised conflict tactics scales, and typologies for severity and mutuality. Journal of Violence and Victims, 19(5), 507-520.

Straus, M. A. (2004). Prevalence of violence against dating partners by male and female university students worldwide. Journal of Violence Against Women, 10(7), 790-811. doi: $10.1177 / 1077801204265552$.

Straus, M. A. (2010). Thirty years of denying the evidence on gender symmetry in partner violence: Implications for prevention and treatment. Journal of Partner Abuse, 1(3), 332-362. doi: 
10.1891/1946-6560.1.3.332.

Walker, L. E. (1979). The battered woman. New York, NY: Harper \& Row.

Wandansari, P. (2013). Hubungan antara kekerasan dalam pacaran dan keterampilan sosial pada wanita dewasa muda (Bentuk literatur tidak dipublikasi). Ditemu kembali dari http://lib.ui.ac.id/naskahringkas/2015-09/S-Pratiwi\%20Wandansari. 